\title{
The incidence of falls among geriatric outpatients in relation to the number and types of drugs taken
}

\author{
Występowanie upadków wśród pacjentów podstawowej opieki zdrowotnej w wieku \\ podeszłym w zależności od liczby i rodzaju zażywanych leków
}

MAGDALENA SYLWIA KAMIŃSKA ${ }^{1, \text { A-G }}$, JACEK BRODOWSKIㄴ, c, D, G, BEATA KARAKIEWICZZ2, G

${ }^{1}$ Department of Primary Health Care, Faculty of Health Sciences, Pomeranian Medical University in Szczecin ${ }^{2}$ Public Health Department, Faculty of Health Sciences, Pomeranian Medical University in Szczecin

A - Study Design, B - Data Collection, C - Statistical Analysis, D - Data Interpretation, E - Manuscript Preparation, $\mathbf{F}$ - Literature Search, $\mathbf{G}$ - Funds Collection

Summary Background. Causes of falls among people over 65 are complex because of age-related involutional changes, comorbidity and polypragmasy that exert negative influence on physical mobility.

Objectives. The purpose of this study is to assess the incidence of falls in geriatric outpatients in relation to the number and type of drugs taken.

Material and methods. The study involved 304 subjects aged 65-100 years, using ambulatory care services. The mean age of the respondents was $78.6 \pm 7.4$. Women constituted $77.3 \%$ of those analyzed, men $-22.7 \%$. This survey-based study was performed using the Geriatric Environmental Inquiry.

Results. A higher number of drugs corresponded with more frequent falls $\left(\chi^{2}\right.$ test; $\left.p<0.05\right)$. Gender was not proved to influence the number of falls $\left(\chi^{2}\right.$ test; $\left.p>0.05\right)$. Gender was proved to influence the number of drugs $\left(\chi^{2}\right.$ test; $\left.p<0.05\right)$. There was a statistically significant relationship between the number of falls and taking hypotensive, anxiolytic and oral antidiabetic drugs $\left(\chi^{2} ; p<0.05\right)$.

Conclusions. 1. The use of a higher number of drugs, irrespective of their pharmacological group, contributes to a higher number of falls, which may be associated with an interaction between particular drugs or be a consequence of a multitude of diseases predisposing to falls. 2. Polypharmacotherapy is a fall risk factor, however it is difficult to say which pharmacology group, discussed in the study, contributes most to the incidence of falls. 3. It is suggested that geriatric pharmacotherapy should be individualized to minimize the incidence of the iatrogenic geriatric syndrome, which predisposes to falls.

Key words: elderly, falls, geriatric pharmacotherapy.

Streszczenie Wstęp. Przyczyny upadków osób po 65. roku życia są złożone ze względu na charakterystyczne dla wieku podeszłego występowanie inwolucyjnych zmian starczych, wielochorobowość i polipragmazję, które sprzyjają upośledzeniu mobilności.

Cel pracy. Ocena występowania upadków wśród pacjentów podstawowej opieki zdrowotnej w wieku podeszłym w zależności od liczby i rodzaju zażywanych leków.

Materiał i metody. Badaniami objęto 304 osoby w wieku 65-100 lat, korzystające ze świadczeń zdrowotnych w warunkach ambulatoryjnych. Odsetek badanych kobiet wyniósł 77,3\%, mężczyzn - 22,7\%. Średnia wieku badanych osób wyniosła 78,6 $\pm 7,4$. Zastosowano metodę sondażu diagnostycznego z wykorzystaniem Geriatrycznego Kwestionariusza Wywiadu Środowiskowego.

Wyniki. Stwierdzono, iż większa liczba przyjmowanych leków przyczynia się do większej liczby upadków (test $\left.\chi^{2} ; p<0,05\right)$. Nie wykazano, aby płeć determinowała liczbę upadków (test $\chi^{2} ; p>0,05$ ). Wykazano jednak zależność pomiędzy płcią a liczbą przyjmowanych leków (test $\chi^{2} ; p<0,05$ ). Odnotowano istotną statystycznie zależność między przyjmowaniem leków hipotensyjnych, leków anksjolitycznych oraz doustnych leków przeciwcukrzycowych a liczbą upadków (test $\chi^{2} ; p<0,05$ ).

Wnioski. 1. Stosowanie większej liczby leków, niezależnie od grupy farmakologicznej, przyczynia się do większej liczby upadków, co może wiązać się ze zjawiskiem interakcji poszczególnych rodzajów leków lub być konsekwencją mnogości chorób predysponujących do upadku. 2. Polifarmakoterapia jest czynnikiem ryzyka upadków, jednakże trudno wskazać, która grupa farmakologiczna, omówiona w niniejszym badaniu, ma decydujący wpływ na występowanie upadków. 3. Wskazuje się na potrzebę indywidualizacji farmakoterapii geriatrycznej, minimalizującej wystąpienie jatrogennego zespołu geriatrycznego, predysponującego do upadków.

Słowa kluczowe: osoby w wieku podeszłym, upadki, farmakoterapia geriatryczna.

Fam Med Prim Care Rev 2016; 18(2): 123-127

\section{Background}

Causes of falls among people over 65 are complex because of comorbidity and polypragmasy, which are typical of old age and, in combination with some functional losses, may impair mobility and produce problems with activities of daily living [1-5]. In the literature, age-related involutional changes as well as pathological states impeding the functioning of postural control system are described as internal causes of falls. External reasons are: environmental factors 
(the development of private and public space), socioeconomic issues (low income, low standard of living, limited access to health and social services, the lack of social support), and behavioral aspects (e.g. polypharmacotherapy, not taking into account differences in drug pharmacokinetics and pharmacodynamics in the organism of an elderly person) [1, 6-9].

Anatomical and functional changes in the gastrointestinal tract of geriatric patients include disorders of the absorption, distribution, metabolism and excretion of drugs [7-14].

Clinical practice shows that polypharmacotherapy raises a risk of adverse effects of negative drug interaction. What is more, a phenomenon observed in geriatric pharmacotherapy is an exacerbation of the disease due to drugs administered for other conditions. The occurring drug-related adverse effects are misinterpreted as a new disease entity, and treated with other medicines, thus creating a sort of a vicious circle in pharmacotherapy, and potentially contributing to the iatrogenic geriatric syndrome [9-14]. Most previous studies conducted in Poland on patients over 60 years of age staying in nursing homes or psychogeriatric wards, focused on the influence of hypotensive drugs on the incidence of falls [15-17]. The aim of this study was to assess the incidence of falls in a group of geriatric outpatients in relation to the number and type of drugs taken.

\section{Material and methods}

The study involved 304 adults aged 65-100 years, using the services of the Regional Occupational Health Care Centre, West Pomeranian Centre for Treatment and Prevention in Szczecin, offering treatment at an outpatients' clinic. Approximately $77.3 \%$ of the patients were women, and $22.7 \%$ - men. The mean age was $78.6 \pm 7.4$.

Principal criteria for the selection of participants were: availability of the patients at the moment of carrying out the study, no symptoms of the exacerbation of the co-existing diseases or other health problems, mental condition of the patients making them able to cooperate during the study and understand the orders of the researcher, ability of the surveyed to move without assistance, as well as conscious and voluntary consent to participate in the research. All subjects who met the above mentioned criteria were included in the study.
This survey-based study was performed using the Geriatric Environmental Inquiry of author's own design. The questionnaire included questions concerning health state, disease and health problems, the number and types of drugs taken, and the circumstances of falls in the past, namely during one year preceding the study. A statistical analysis was performed using Statistica for Windows PL. The accepted significance level was $p<0.05$.

The study was conducted with the consent of the Bioethical Commission of the Pomeranian Medical University in Szczecin (permission number KB-0080/141/09).

\section{Results}

Out of all respondents, 233 subjects had falls in the year preceding the study. The first to be analysed was the correlation between gender of the respondents and their falls. Both among people who had and those who did not have falls, the majority were women (185 women and 50 men, i.e. $79.40 \%$ and $70.42 \%$ respectively). Statistical calculations showed that age did not significantly contribute to falls among people at the geriatric age (test $\chi^{2} ; p>0.05$ ). As the next step, the authors analysed the correlation between gender and the number of falls. Gender was not proved to influence the number of falls (test $\chi^{2} ; p>0.05$ ).

The authors analyzed the relationship between the number of drugs taken by respondents and their falls. A group of non-fallers included slightly more patients who did not take any drugs. A group of fallers, on the other hand, incorporated slightly more patients taking more than ten drugs. The study did not confirm a statistically significant relationship between the occurrence of falls and the number of drugs taken by respondents (test $\left.\chi^{2} ; p>0.05\right)$ (Tab. 1). Gender was proved to influence the number of drugs (test $\chi^{2} ; p<0.05$ ). In the study group, women took greater number of drugs than men (Tab. 2).

Next, the authors analyzed the relationship between the number of drugs taken by respondents and the number of falls. It was noticed that an increasing number of falls in a group was accompanied by a higher number of patients taking more than ten drugs and a lower number of patients who did not take any drugs. It was concluded that a higher number of drugs contributed to a higher number of falls (test $\left.\chi^{2} ; p<0.05\right)($ Tab. 3).

Table 1. Relationship between the number of drugs taken by respondents and the occurrence of falls

\begin{tabular}{|c|c|c|c|c|c|c|c|c|}
\hline \multirow{2}{*}{$\begin{array}{l}\text { Number } \\
\text { of drugs }\end{array}$} & \multicolumn{2}{|c|}{ Fall - yes } & \multicolumn{2}{|c|}{ Fall - no } & \multicolumn{2}{|c|}{ Total } & \multirow{2}{*}{$\begin{array}{l}\begin{array}{l}\text { Pearson's } \\
\chi^{2} \text { test }\end{array} \\
6.56\end{array}$} & \multirow{2}{*}{$\frac{p}{0.08}$} \\
\hline & $n$ & $\%$ & $\bar{n}$ & $\%$ & $\bar{n}$ & $\%$ & & \\
\hline 0 & 26 & 11.16 & 14 & 19.72 & 40 & 13.15 & & \\
\hline $1-3$ & 92 & 39.48 & 33 & 46.48 & 125 & 41.11 & & \\
\hline $4-10$ & 9 & 3.86 & 2 & 2.82 & 11 & 3.61 & & \\
\hline$>10$ & 106 & 45.49 & 22 & 30.99 & 128 & 42.10 & & \\
\hline Total & 233 & 76.60 & 71 & 23.40 & 304 & 100.00 & & \\
\hline
\end{tabular}

Table 2. Relationship between the number of drugs taken by respondents and the gender

\begin{tabular}{|l|l|l|l|l|l|l|l|l|}
\hline \multirow{2}{*}{$\begin{array}{l}\text { Number } \\
\text { of drugs }\end{array}$} & \multicolumn{3}{|l|}{ Women } & \multicolumn{3}{l|}{ Men } & $\begin{array}{l}\text { Total } \\
\chi^{2} \text { test }\end{array}$ & \\
\cline { 2 - 9 } & $n$ & $\%$ & $n$ & $\%$ & $n$ & $\%$ & 6.01 & 0.04 \\
\hline $1-3$ & 28 & 11.91 & 13 & 18.84 & 41 & 13.49 & & \\
\hline $4-10$ & 201 & 85.53 & 51 & 73.53 & 252 & 82.89 & & \\
\hline$>10$ & 6 & 2.55 & 5 & 7.25 & 11 & 3.62 & & \\
\hline Total & $\mathbf{2 3 5}$ & $\mathbf{7 7 . 3 3}$ & $\mathbf{6 9}$ & $\mathbf{2 2 . 7 0}$ & $\mathbf{3 0 4}$ & $\mathbf{1 0 0 . 0 0}$ & & \\
\hline
\end{tabular}


Both fallers and non-fallers took the same types of medicines. It was observed, however, that patients who had falls considerably more often used hypotensive drugs (93.13\%), and more often took oral antidiabetic drugs (24.89\%) (Fig. 1).

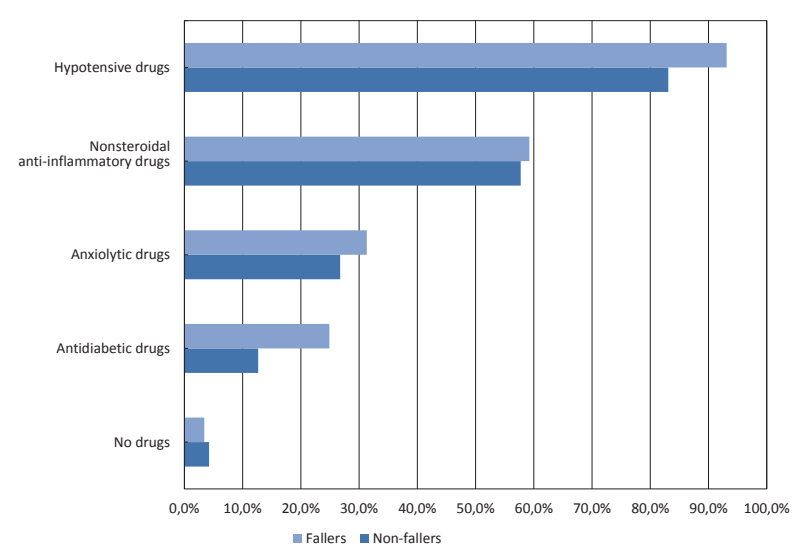

Figure 1. The type of drugs taken by respondents in relation to the occurrence of falls

As the next step, the authors performed a statistical analysis of the relationship between the drugs taken by respondents due to co-existing diseases and the occurrence of falls.
A statistically significant relationship between the occurrence of falls and using hypotensive drugs (angiotensin-converting-enzyme inhibitors and calcium channel blockers) was not confirmed (test $\chi^{2} ; p>0.05$ ). There was, however, a statistically significant relationship between taking the above mentioned drugs and the number of falls (test $\chi^{2}$; $\mathrm{p}<0.05)$ - a higher number of falls corresponded with a higher number of patients taking hypotensive drugs (Tab. 4).

The study did not demonstrate a statistically significant relationship between the occurrence of falls and using nonsteroidal anti-inflammatory drugs (NSAIDs) (acetylsalicylic acid at cardiologic doses) (test $\chi^{2} ; p>0.05$ ). However, users of NSAIDs considerably more often reported three falls than patients who did not take these drugs (Tab. 5). This relationship was not statistically significant (test $\chi^{2} ; p>0.05$ ).

A statistically significant relationship between the occurrence of falls and taking anxiolytic drugs (benzodiazepine derivatives - alprazolam) was not confirmed (test $\chi^{2}$; $p>0.05)$. Nevertheless, it was proved that three falls were significantly more often noted among users than non-users of such drugs. In the latter group, on the other hand, more patients fell once or did not fall at all. It was found that there was a statistically significant relationship between the number of falls and taking anxiolytic drugs (test $\chi^{2} ; p<0.05$ ). Respondents taking anxiolytic drugs fell considerably more often than those did not use them (Tab. 6).

\begin{tabular}{|c|c|c|c|c|c|c|c|c|c|c|c|c|}
\hline \multirow{3}{*}{$\begin{array}{l}\text { Number } \\
\text { of falls }\end{array}$} & \multicolumn{8}{|c|}{ Number of drugs } & \multirow{2}{*}{\multicolumn{2}{|c|}{ Total }} & \multirow{3}{*}{$\begin{array}{l}\text { Pearson's } \\
\chi^{2} \text { test } \\
21.42\end{array}$} & \multirow{3}{*}{\begin{tabular}{|l}
$p$ \\
0.00
\end{tabular}} \\
\hline & \multicolumn{2}{|l|}{0} & \multicolumn{2}{|l|}{$1-3$} & \multicolumn{2}{|c|}{$4-10$} & \multicolumn{2}{|l|}{$>10$} & & & & \\
\hline & $n$ & $\%$ & $n$ & $\%$ & $n$ & $\%$ & $n$ & $\%$ & $n$ & $\%$ & & \\
\hline 0 & 14 & 19.72 & 34 & 47.89 & 2 & 2.82 & 21 & 29.58 & 71 & 23.35 & & \\
\hline 1 & 12 & 12.50 & 46 & 47.92 & 6 & 6.25 & 32 & 33.33 & 96 & 31.58 & & \\
\hline 2 & 8 & 12.90 & 25 & 40.32 & 1 & 1.61 & 28 & 45.16 & 62 & 20.40 & & \\
\hline$\geq 3$ & 6 & 8.00 & 20 & 26.67 & 2 & 2.67 & 47 & 62.67 & 75 & 24.67 & & \\
\hline Total & 40 & 13.16 & 125 & 41.12 & 11 & 3.61 & 128 & 42.11 & 304 & 100.00 & & \\
\hline
\end{tabular}

\begin{tabular}{|c|c|c|c|c|c|c|c|c|}
\hline \multirow[t]{2}{*}{$\begin{array}{l}\text { Number } \\
\text { of falls }\end{array}$} & \multicolumn{2}{|c|}{$\begin{array}{l}\text { Hypotensive } \\
\text { drugs - yes }\end{array}$} & \multicolumn{2}{|c|}{$\begin{array}{l}\text { Hypotensive } \\
\text { drugs - no }\end{array}$} & \multicolumn{2}{|c|}{ Total } & \multirow{2}{*}{\begin{tabular}{|l}
$\begin{array}{l}\text { Pearson's } \\
\chi^{2} \text { test }\end{array}$ \\
3.21
\end{tabular}} & \multirow{2}{*}{$\frac{p}{0.02}$} \\
\hline & $n$ & $\%$ & $n$ & $\%$ & $n$ & $\%$ & & \\
\hline 0 & 55 & 77.46 & 16 & 22.54 & 71 & 23.35 & & \\
\hline 1 & 75 & 78.13 & 21 & 21.88 & 96 & 40.94 & & \\
\hline 2 & 53 & 85.48 & 9 & 14.52 & 62 & 26.72 & & \\
\hline$\geq 3$ & 70 & 93.33 & 5 & 6.67 & 75 & 32.32 & & \\
\hline Total & 253 & 58.88 & 51 & 41.12 & 304 & 100.00 & & \\
\hline
\end{tabular}

\begin{tabular}{|c|c|c|c|c|c|c|c|c|}
\hline \multirow{2}{*}{$\begin{array}{l}\text { Number } \\
\text { of falls }\end{array}$} & \multicolumn{2}{|c|}{ NSAIDs - yes } & \multicolumn{2}{|c|}{ NSAIDs - no } & \multicolumn{2}{|c|}{ Total } & \multirow{2}{*}{$\begin{array}{l}\text { Pearson's } \\
\chi^{2} \text { test } \\
3.21\end{array}$} & \multirow{2}{*}{$\begin{array}{l}p \\
0.36\end{array}$} \\
\hline & $n$ & $\%$ & $n$ & $\%$ & $n$ & $\%$ & & \\
\hline 0 & 42 & 23.46 & 29 & 23.20 & 71 & 23.35 & & \\
\hline 1 & 51 & 28.49 & 45 & 36.00 & 96 & 40.94 & & \\
\hline 2 & 36 & 20.11 & 26 & 20.80 & 62 & 26.72 & & \\
\hline$\geq 3$ & 50 & 27.93 & 25 & 20.00 & 75 & 32.32 & & \\
\hline Total & 179 & 58.88 & 125 & 41.12 & 304 & 100.00 & & \\
\hline
\end{tabular}




\begin{tabular}{|l|l|l|l|l|l|l|l|l|}
\hline \multicolumn{2}{|l|}{ Table 6. Relationship between taking anxiolytic drugs and the number of falls } \\
\hline $\begin{array}{l}\text { Number } \\
\text { of falls }\end{array}$ & $\begin{array}{l}\text { Anxiolytic drugs } \\
- \text { yes }\end{array}$ & \multicolumn{2}{l|}{$\begin{array}{l}\text { Anxiolytic drugs } \\
- \text { no }\end{array}$} & \multicolumn{2}{l|}{ Total } & $\begin{array}{l}\text { Pearson's } \\
\chi^{2} \text { test }\end{array}$ & $p$ \\
\cline { 2 - 11 } & $n$ & $\%$ & $n$ & $\%$ & $n$ & $\%$ & 15.47 & 0.00 \\
\hline 0 & 18 & 19.57 & 53 & 25.00 & 71 & 23.35 & & \\
\hline 1 & 19 & 20.65 & 77 & 36.32 & 96 & 40.94 & & \\
\hline 2 & 20 & 21.74 & 42 & 19.81 & 62 & 26.72 & & \\
\hline$\geq 3$ & 35 & 38.04 & 40 & 18.87 & 75 & 32.32 & & \\
\hline Total & $\mathbf{9 2}$ & $\mathbf{3 1 . 5 7}$ & $\mathbf{2 1 2}$ & $\mathbf{6 9 . 7 3}$ & $\mathbf{3 0 4}$ & $\mathbf{1 0 0 . 0 0}$ & & \\
\hline
\end{tabular}

Table 7. Relationship between taking oral antidiabetic drugs and the occurrence of falls

\begin{tabular}{|c|c|c|c|c|c|c|c|c|}
\hline \multirow{2}{*}{$\begin{array}{l}\text { Oral antidia- } \\
\text { betic drugs }\end{array}$} & \multicolumn{2}{|c|}{ Fall - yes } & \multicolumn{2}{|c|}{ Fall - no } & \multicolumn{2}{|c|}{ Total } & \multirow{2}{*}{$\begin{array}{l}\text { Pearson's } \\
\chi^{2} \text { test } \\
4.72\end{array}$} & \multirow{2}{*}{$\begin{array}{l}p \\
0.02\end{array}$} \\
\hline & $n$ & $\%$ & $n$ & $\%$ & $n$ & $\%$ & & \\
\hline Yes & 58 & 24.89 & 9 & 12.68 & 67 & 22.03 & & \\
\hline No & 175 & 75.11 & 62 & 87.32 & 237 & 77.96 & & \\
\hline Total & 233 & 76.60 & 71 & 23.40 & 304 & 100.00 & & \\
\hline
\end{tabular}

Table 8. Relationship between taking oral antidiabetic drugs and the number of falls

\begin{tabular}{|c|c|c|c|c|c|c|c|c|}
\hline \multirow[t]{2}{*}{$\begin{array}{l}\text { Number } \\
\text { of falls }\end{array}$} & \multicolumn{2}{|c|}{$\begin{array}{l}\text { Oral antidiabetic } \\
\text { drugs - yes }\end{array}$} & \multicolumn{2}{|c|}{$\begin{array}{l}\text { Oral antidiabetic } \\
\text { drugs - no }\end{array}$} & \multicolumn{2}{|c|}{ Total } & \multirow{2}{*}{$\begin{array}{l}\text { Pearson's } \\
\chi^{2} \text { test } \\
8.04 \\
\end{array}$} & \multirow{2}{*}{\begin{tabular}{|l|}
$p$ \\
0.04 \\
\end{tabular}} \\
\hline & $n$ & $\%$ & $n$ & $\%$ & $n$ & $\%$ & & \\
\hline 0 & 9 & 13.43 & 62 & 26.16 & 71 & 23.35 & & \\
\hline 1 & 20 & 29.85 & 76 & 32.07 & 96 & 40.94 & & \\
\hline 2 & 14 & 20.90 & 48 & 20.25 & 62 & 26.72 & & \\
\hline$\geq 3$ & 24 & 35.82 & 51 & 21.52 & 75 & 32.32 & & \\
\hline Total & 67 & 22.03 & 237 & 77.96 & 304 & 100.00 & & \\
\hline
\end{tabular}

There was a statistically significant relationship between the use of oral antidiabetic drugs (oral antihyperglycemic agents namely biguanide derivatives - metformin; insulin had not been used) and the occurrence of falls (test $\chi^{2}$; $p<0.05)$. Fallers took the above mentioned drugs considerably more often than non-fallers (Tab. 7).

Furthermore, considerably more patients taking oral antidiabetic drugs reported three falls than those who did not use such medicines. Conversely, the latter group included more respondents who did not fall at all (Tab. 8).

\section{Discussion}

An analysis of the results obtained in this study demonstrated that a higher number of drugs, irrespective of their pharmacological group, contributed to a higher number of falls. A higher number of falls corresponded with a higher proportion of respondents taking hypotensive, anxiolytic and oral antidiabetic drugs.

Agostini et al. [18] proved that a risk of the impaired postural control was increasing with the number of drugs taken by patients. The findings of Huang et al. [19] confirm that ingestion of four or more drugs, irrespective of their pharmacological group, raises a risk of falls. According to Shuto et al. [20] exposure to falls is greater among patients taking hypotensive and psychotropic drugs. The research conducted by Gales and Menard [21] shows that the incidence of falls among patients with cardiac insufficiency is related to digoxin therapy, benzodiazepine treatment, or taking at least three psychoactive drugs. The relationship between hypotensive drugs and a risk of falls in the future was also confirmed by the results reported by Gribbin et al. [22]. Rhalimi et al. [23] demonstrated that a risk of falls is enhanced by hypnotic and anxiolytic drugs. Kallin et al. [24], on the other hand, provide evidence that a risk of falls can be significantly increased not necessarily by depressive symptoms themselves, but by taking antidepressants. The study of Nurminen et al. [25] proves that taking two or more medications from the group of benzodiazepines, and at the same time two or more antipsychotic drugs, entails a higher risk of fractures. As results from the studies conducted by Walker et al. [26], the use of nonsteroidal anti-inflammatory drugs is a predictive factor of falls, causing a tenfold increase in their likelihood. Furthermore, the team of Rozenfeld et al. [27] observed that the occurrence of falls is related to both prescription and over-the-counter (OTC) medicines.

Scientific reports indicate that falls may be a side-effect of taking certain drugs, but on the other hand, medicines taken may be associated with the presence of diseases predisposing to falls $[9,28]$.

\section{Conclusions}

1. The use of a higher number of drugs, irrespective of their pharmacological group, contributes to a higher number of falls, which may be associated with an interaction between particular drugs or be a consequence of a multitude of diseases predisposing to falls.

2. Polypharmacotherapy is a fall risk factor, however it is difficult to say which pharmacology group contributes most to the incidence of falls.

3. It is suggested that geriatric pharmacotherapy should be individualized to minimize the incidence of the iatrogenic geriatric syndrome, which predisposes to falls. 
Source of funding: The research was funded by the Pomeranian Medical University in Szczecin.

Conflict of interest: The authors declare no conflict of interests.

\section{References}

1. Kamińska MS. Rola pielęgniarki rodzinnej w prewencji upadków w grupie pacjentów w wieku geriatrycznym. Fam Med Prim Care Rev 2013; 15(1): 21-26.

2. Kamińska MS, Brodowski J, Karakiewicz B. Analiza ryzyka wystąpienia upadków wśród pensjonariuszy Domu Pomocy Społecznej w Szczecinie. Fam Med Prim Care Rev 2011; 13(4): 708-712.

3. Kamińska M, Brodowski J, Bażydło M, i wsp. Ocena zagrożenia niedożywieniem pacjentów w wieku geriatrycznym z wykorzystaniem Testu Mini Nutritional Assessment (MNA). Fam Med Prim Care Rev 2010; 12(4): 1035-1039.

4. Panaszek B, Machaj Z, Bogacka E, et. al. Chronic disease in the elderly. Pol Arch Med Wew 2009; 119(4): $248-254$.

5. Tomasik T, Gryglewska B, Windak A, et al. Hypertension in the elderly: how to treat patients in 2013? Pol Arch Med Wew 2013; 123(7-8): 409-416.

6. Skalska A, Żak M. Upadki - ocena ryzyka, postępowanie prewencyjne. Stand Med 2007; 4(2): 167-174.

7. Walasik L. Podeszły wiek jako czynnik ryzyka wielochorobowości. Nowa Klin 2010; 17(1): 71-75.

8. WHO Global Report on Falls Prevention in Older Age. Genova: World Health Organization; 2007.

9. Rosenthal TC, Williams MB, Naughthon BJ, eds. Geriatria. Pączek L, Niemczyk M, red. wyd. pol. Lublin: Wydawnictwo Czelej; 2009.

10. Woroń J, Filipczak-Bryniarska I, Goszcz A. The brand-name and generic drugs in geriatric pharmacotherapy. Geriatria 2011; 5(1): 47-54.

11. Hanlon JT, Lindbland C, Maher RL, et al. Geriatric pharmacotherapy. In: Tallis RC, Fillit HM, eds. Geriatric medicine and gerontology. 6th ed. Amsterdam: Elsevier Science Limited; 2003: 1289-1297.

12. Meredith S, Feldman PH, Frey D. Possible medication errors in home healthcare patients. J Am Geriatr Soc 2001; 49(6): 719-724.

13. Jörgensen $T$, Johansson S, Kennerfalk A, et al. Prescription drug use, diagnoses, and healthcare utilization among the elderly. Ann Pharmacother 2001; 35(9): 1004-1009.

14. Ahmad A, Mast MR, Nijpels G, et al. Identification of drug-related problems of elderly patients discharged from hospital. Patient Prefer Adherence 2014; 4(8): 155-165.

15. Cegła B, Faleńczyk K, Ślusarz R, i wsp. Ocena ryzyka wystąpienia upadków u osób w starszym wieku. Valetudinaria - Post Med Klin Wojsk 2006; 11(1): 67-73.

16. Borzym A. Częstość występowania upadków u chorych w podeszłym wieku hospitalizowanych w oddziale psychogeriatrycznym. Post Psychiatr Neurol 2003; 12(1): 55-60.

17. Żak M, Grylewska B. Upadki pacjentów geriatrycznych z nadciśnieniem tętniczym - ocena ryzyka dokonywana po roku od upadku. Nadciśn Tętn 2005; 9(2): 112-117.

18. Agostini JV, Han L, Tinetti ME. The relationship between number of medication and weight loss or impaired balance in older adults. J Am Geriatr Soc 2004; 52 (10): 1719-1723.

19. Huang ES, Karter AJ, Danielson KK, et al. The association between the number of prescription medications and incident falls in a multi-ethnic population of adult type-2 diabetes patients: the diabetes and aging study. J Gen Intern Med 2010; 25(2): $141-146$.

20. Shuto $\mathrm{H}$, Imakyure $\mathrm{O}$, Matsumoto J, et. al. Medication use as a risk factor for inpatient falls in an acute care hospital: a casecrossover study. Br J Clin Pharmacol 2010; 69(5): 535-542.

21. Gales BJ, Menard SM. Relationship between the administration of selected medications and falls in hospitalized elderly patients. Ann Pharmacother 1995; 29(4): 354-358.

22. Gribbin J, Hubbard R, Gladman J, et al. Risk of falls associated with antihypertensive medication: population-based case-control study. Age Ageing 2010; 39(5): 592-597.

23. Rhalimi M, Helou R, Jaecker P. Medication use and increased risk of falls in hospitalized elderly patients: a retrospective, case-control study. Drugs Aging 2009; 26(10): 847-852.

24. Kallin K, Lundin-Olsson L, Jensen J, et al. Predisposing and precipitating factors for falls among older people in residential care. Public Health 2002; 116(5): 263-271.

25. Nurminen J, Puustinen J, Piirtola M, et al. Psychotropic drugs and the risk of fractures in old age: a prospective population-based study. BMC Public Health 2010; 6(10): 396.

26. Walker PC, Alrawi A, Mitchell JF, et al. Medication use as a risk factor for falls among hospitalized elderly patients. Am J Health Syst Pharm 2005: 62(23): 2495-2499.

27. Rozenfeld S, Camacho LA, Veras P. Medication as a risk factor for falls in older women in Brazil. Rev Panam Salud Publica 2003; 13(6): 369-375.

28. Boyle N, Naganathan V, Cumming RG. Medication and falls: risk and optimization. Clin Geriatr Med 2010; $26(4)$ : $583-605$.

Address for correspondence:

Dr n. med. Magdalena Sylwia Kamińska

Zakład Podstawowej Opieki Zdrowotnej

Wydział Nauk o Zdrowiu PUM

ul. Żołnierska 48

71-210 Szczecin

Tel.: +48 692 866-677

E-mail: magdalena.kaminska@pum.edu.pl

Received: 15.05.2015

Revised: 08.11.2015

Accepted: 15.11.2015 